\title{
Fundamentul moral al dreptului în Roma Antică ${ }^{1}$
}

\section{Cristinel Ioan MURZEA ${ }^{1}$ **}

1 Universitatea Transilvania din Brasov;

cristinel.murzea@unitbv.ro

*Correspondence: cristinel.murzea@unitbv.ro

Rezumat: Normativitatea sistemului social politic este un postulat al genezei și al organizării statului, privit ca un sistem de sisteme în care evident subsistemul dreptului apare în conținut și formă ca o realitate obiectivă ce-și are fundamentul în preceptele morale ale societății respective. Pe aceste coordonate între normele juridice Jus și cele de ordin moral FAS a existat o congruență perfectă în cadrul societății antice romane arătându-se în mod explicit că principiile dreptului roman se definesc prin principii de ordin moral precum honestevivere, alterum non laedere, suum cuique tribuere.

Cuvinte cheie: normă socială, drept, morală, religie, instituție juridică
Citation: Murzea C.I. (2021)

Fundamentul moral al dreptului în

Roma antică. Revista Etică si Deontologie. 1(1), 89-94

https://doi.org/10.52744/RED.2021.01.11

Publisher's Note: RED stays neutral with regard to jurisdictional claims in published maps and institutional affiliations.

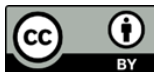

Copyright: (C) 2021 by the authors. Submitted for possible open access publication under the terms and conditions of the Creative Commons

Attribution (CC BY) license (https://creativecommons.org/ licenses/by/4.0/).

\footnotetext{
${ }^{1}$ Articol prezentat în cadrul Conferinței Internaționale Valorile Etice în Societatea Actuală - VESA 2021 (3-5 iunie).
} 


\section{Introducere}

Reflectând valorile consacrate într-o societate dată, morala va acționa implicit ca un factor de configurare al dreptului, aceasta cu atât mai mult cu cât se conturează în plan conceptual în axioma conform căreia valorile de natură etică se obiectivează în adevărate postulate, în însăși principii de viață care se vor transpune implicit în mod simetric și în sistemul normativ juridic oferit de dreptul pozitiv.

Principiile ce guvernează conduita morală în cadrul societății sunt experiențe asumate și respectate într-o practică socială îndelungată, fiind supuse permanent unui proces dinamic pe de o parte valorizator, iar pe de alta formativ-educativ. În acest context un mare filozof al dreptului (Djuvara, 1936, p. 11) enunța un adagiu consacrat afirmând că s-ar produce o mare eroare majoră în „a crede că un principiu de drept, morală sau justiție este produsul unei pure speculațiuni și că ar apare în mintea noastră înaintea unei experiențe".

\section{Dreptul roman și normele morale}

În acest context încă juriștii antici au încercat să definească dreptul tocmai prin principiile sale, care au fost într-o relație de conexiune și interferenţă directă cu principiile și normele morale. Este, în acest sens definitorie și conclusivă formularea lapidară dată de către Ulpianus care afirma - „Juris praecepta sunt haec: honeste vivere, alterum non laedere suum cuique tribuere" - (principiile dreptului sunt acestea: a trăi în mod onorabil, a nu vătăma pe altul, a da fiecăruia ceea ce este al său) (Molcut, Oancea, 1993, p. 6). Din aforismul de mai sus rezultă în mod neechivoc faptul că alături de două principii consacrate de drept care și ele au la rândul lor o încărcătură de ordin etic, stă un principiu universal din sfera moralei conform căruia sensul vieții conform tradiției și mentalității romane este acela de a trăi în mod onorabil. Confuzia între drept morală și religie este o realitate de necontestat, ea fiind prezentă la toate popoarele antice, căci întotdeauna forța dreptului a fost asociată cu voința zeilor, cât și cu tradițiile și obiceiurile zămislite din vremuri ancestrale.

Asociind dreptul quiritar (dreptul folosit exclusiv în raporturile născute între cetățenii romani) cu tradițiile și morala societății antice născute în cetatea eternă Roma, ce avea să devină un stat universal, întins pe trei continente, dreptul roman s-a impus în patrimoniul civilizației universale.

Formulările lapidare consacrate în maxime și adagii, care ele însele au fost o adevărată chintesență a principiilor fundamentale pe care s-a construit întregul eșafodaj juridic ajuns la nivel de știință a dreptului - deci ca jurisprudență - avea să situeze Roma antică ca fondatoare a civilizației juridice de stat întemeiat pe principiile universale ce definesc normalitatea priviră lato sensu adică ca o universalitate de reguli ce guvernează și ordonează conduita umană.

Principiile fundamentale ale dreptului roman întemeiate pe valorile consacrate de ordin moral-etic ce-și aveau sorgintea în tradițiile și obiceiurile ce se pierdeau în 
negura timpurilor, după cum ne arătau iluștrii jurisconsulți romani (Oancea, 2009), s-au constituit în adevărate repere și axe viitoare în ceea ce privește valorificarea câmpului teoretic și practic oferit de realitatea juridică postumă.

În acest sens doctrina juridică de specialitate (Hanga, 1978; Perrot, 1937) avea să recunoască un adevărat postulat universal conform căruia sistemul juridic creat de Roma antică în cele peste 12 secole de existență s-a constituit într-un vast teren de validare a principiilor fundamentale ale dreptului, fiind totodată și izvorul teoretic ce a stat la baza principalelor instituții juridice viitoare, care în epoca modernă s-au obiectivat în vastele coduri ce aveau să reprezinte o formă calitativ superioară în ceea ce privește tehnica legislativă. S-a subliniat totodată paradigma conform căreia „dreptul roman nu a rămas un simplu document arheologic, așa cum este cazul altor legislații din antichitate, ci a trăit o viață proprie, a depășit sub aspectul formei sale limitele societății care l-a generat și a exercitat o influență hotărâtoare asupra dreptului de mai târziu" (Molcut, Oancea, 1993, p. 9).

Toate aceste postulate teoretice își găsesc explicația în aceea că între morală și drept există o congruență evidentă, lucru ce arată că atunci când este analizată conduita unui individ în societate se are în vedere aspectele de fond ce privesc încadrarea acesteia în concordanță cu interesul general promovat în societate, cu aspirațiile și valorile colective asumate și conservate prin mijloace mai mult sau mai puțin coercitive de către organele și instituțiile abilitate în acest sens.

La romani, ca de fapt și la alte popoare antice, sistemul normativ juridic și-a avut originile în normele sociale de ordin moral, astfel morala va fi într-o formulare sintetică antecesoarea dreptului în accepțiunea generică. În acest sens, Guy Durand afirma în mod ritos faptul că - „Morala a servit totdeauna ca o proto-legislație socială” (Durand, 1986, p. 285). Încă din perioada prestatală a Romei, cetatea ce avea să reprezinte statul etalon al antichității s-a pus problema legală de raportul biunivoc ce se naște între drept și dreptate, între just și injust.

În acest context exista o unanimitate de opinie în doctrina filosofiei juridice (del Vecchio, 1995) referitoare la preemțiunea moralei asupra dreptului cât și a implicațiilor directe și evidente ale normelor de comportament statuate la nivelul obiceiurilor și cutumelor în tiparul viitoarelor izvoare formale de drept. În acest sens, reputați autori (Djuvara, 1913, p. 49) atunci când abordează raportul dintre morală și drept în teze consacrate din domeniul filosofiei dreptului, arată că fundamentul legitimității morale a dreptului pozitiv s-au constituit în - „aspecte centrale ale filosofiei dreptului, fiind un adevărat cap Horn în ceea ce privește sediul materiei" (n.n.).

A trăi în mod onest - honestum vivere - era un comandament impus de valorile de ordin moral care-și găseau expresia deplină în ceea ce privește juridicitatea privită ca proces de realizare a dreptului în sintagma - suum cuique tribuere - ce se constituia aşadar într-un postulat al justiției distributive.

Raportul strâns între drept și morală se explică în Roma antică pe de o parte prin păstrarea valorilor tradiționale specifice ethosului roman din perioada genezei orașului cetate, care conform tradiției legendare a fost realizată în anul 754 î.e.n. de Romulus și Remus, fiii zeului războiului Marte, păstrătorii simbolici și originari ai domeniului heredial, cât și datorită influenței covârșitoare, pe de altă parte, a religiei, 
căci o încălcare a principiilor morale de viață ar fi însemnat o atingere adusă voinței zeilor care au înzestrat poporul roman cu forța dreptului.

Această dependență de morală și religie a dreptului roman va da conținut și formă principalelor reglementări și instituții juridice apărute în statul roman încă din momentul cristalizării societății politice și își vor găsi cadrul normativ în ceea ce s-a numit „,carmen necessarium,, al cetățenilor romani, respectiv Legea celor XII Table.

Caracterul formalist rigid al dreptului făcea ca actele juridice încheiate în baza normelor de drept în epoca străveche și veche, să fie încheiate prin proceduri riguroase, solemne, încărcate de formule magice în care se invocă voința zeilor, cât și de gesturi și simboluri rituale.

Toate acestea își aveau sorgintea în principii de viață care răspundeau unui cod etic ce avea drept finalitate respectarea obiceiurilor, a tradițiilor cât și a vechii morale ce trebuia să guverneze conduita cetățenilor romani.

În acest context în literatura de specialitate (Molcuț, 2011, p. 49) s-a arătat că dreptul quiritar era adresat exclusiv cetățenilor romani, el neputând fi utilizat în raporturile născute cu cetățenii străini, cu peregrinii, căci acestora nu li se acorda privilegiul de a beneficia de - jus civilae - privit lato sensu. Prin formulele complicate extrem de solemne, cât și prin invocarea zeităților romane se valorifica pe de o parte morala tradițională romană, dar în același timp se crea un statut special sub aspectul drepturilor și libertăților publice quiritilor.

Pater familias era prima persoană chemată să asigure viața de familie în concordanță cu morala și obiceiurile vechilor romani.

Evoluția statului roman, expansiunea sa teritorială continuă cât și faptul că Roma depășește statutul de - polis - devenind un stat universal al cărui centru avea să devină Marea Mediterană asumată de romani ca „marae nostrum” determină o nouă viziune asupra dreptului care din ce în ce mai mult s-a emancipat de sub haina religiei, însă în continuare normele morale continuă să rămână arhetipul în cadrul căruia s-au realizat normele juridice în epoca clasică, epocă în care intervenția pretorului a fost decisivă în procesul de adaptare, de modificare și chiar de reinventare a dreptului quiritar chemat să răspundă noilor provocări determinate de noile forme de configurare a dreptului.

Continuă și acum raportul de interferență între drept și morală. Astfel, dacă raportul dintre „Jus” și „Fas” va fi evident, adică separarea normelor juridice de cele religioase, asistăm la o relativă independență și față de normele morale. Interpretând definiția dreptului dată de către Celsus care arată că - „Jus est ars aequi et boni” - binele și echitatea fiind concepte de ordin moral, renumitul filosof al dreptului, Paul Roubier afirma că de fapt aici se pot identifica primii pași care „au separat dreptul de morală” (Roubier , 1951, p. 41) în plan conceptual.

Elementul de constanță și de echivalență între drept și morală în opinia jurisconsultului Celsus îl reprezenta conceptul de echitate.

Se poate astfel lesne constata că între drept și moral „echitatea,, apare ca liantul necesar care sub o dublă semantică acoperă atât o valoare de ordin moral cât și un concept juridic menit să restabilească o ordine socială încălcată.

Din rațiuni de echitate se poate constata că în procesul de realizare a dreptului obiectiv roman, în special în ceea ce privește dreptul civil, s-a încercat și în mare 
măsură s-a realizat ca prin sistemul legislativ să se asigure o deplină egalitate juridică cetățenilor romani, priviți ca subiecte individuale de drept, care intrând în circuitul civil, ca urmare a manifestării lor de voință, încheie raporturi juridice de pe poziții de deplină egalitate juridică, mai ales în materia obligațiilor.

Din însăși mecanismul de naștere al contractelor, din întâlnirea pe deplin concordantă a ofertei cu acceptarea ei, vede atât în contractele solemne, reale sau consensuale că părțile contractului sunt privite ca purtătoare de drepturi și obligații încercându-se să se asigure un raport de echivalență între părți (Popa, 2004).

În acest context, conferind contractului putere de lege, se punea în acțiune adagiul „Pacta sunt servanda,, conform căruia autoritatea și forța legii avea să fie translatată și în raportul individual de drept născut între subiecți determinați de drept, fie ei creditori sau debitori.

Mai mult chiar, plecând de la afirmarea principiului echității constatăm că pretorul în calitatea lui de principal magistrat judiciar, atunci când constată că pretențiile unei părți sunt legitime, îi punea acesteia la dispoziție acel mijloc juridic necesar valorificării interesului său subiectiv cu toate că cesta nu era recunoscut în plan juridic, instituind pe cale mediată, procedurală, un nou drept subiectiv ca atare.

Deși edictul pretorului nu se constituia într-un izvor formal de drept, totuși prin acesta, acest magistrat judiciar, plecând de la premisele de ordin moral ce aveau la bază echitatea cât și ideea de just, de rezonabil, conferea părții îndrituite fie posibilitatea de a promova o acțiune sau dimpotrivă o excepțiune prin intermediul căreia să-și pună în lucrare dreptul ca atare.

Pe cale de consecință, doar în sens formal pretorul nu era creator de drept, căci activitatea sa depășea din rațiuni de ordin moral poziția în care el practic doar punea în mișcare dreptul civil, privit ca o realitate statică, perenă, identică în conținut și formă cu substanțialitatea sa.

\section{3. În loc de concluzii}

S-a afirmat (Jacotă, 1977, p. 30) în acest sens faptul că dreptul pretorian reprezintă - „sufletul viu al dreptului roman” - el valorificând pe de o parte practica judiciară, doctrina de specialitate cât și o interpretare sistematică în sensul de a produce efecte a normelor juridice din statul roman.

Astfel constatăm că principii de ordin moral aveau să influențeze pe cale mediată evoluția sistemului legislativ roman privit în dinamica sa din perspectiva celor 12 secole de existență.

$\mathrm{Nu}$ trebuie uitat rolul cutumei, al obiceiurilor nejuridice, care vor influența procesul de trecere de la societatea gentilică la societatea politică, și care cu timpul vor fi asumate de clasele conducătoare din societate, în măsura în care le acopereau interesele, ele devenind obiceiuri juridice, fiind clasificate ca atare, între izvoarele formale de drept roman.

Evident aspectele ce țineau de moravurile, obiceiurile, tradițiile cât și de conduita cerută de statul roman se vor transpune în mod sensibil în sistemul normativ roman.

Morala a însoțit sistemul legislativ roman în evoluția lui istorică atât în epoca veche, cea clasică și chiar în epoca postclasică. 


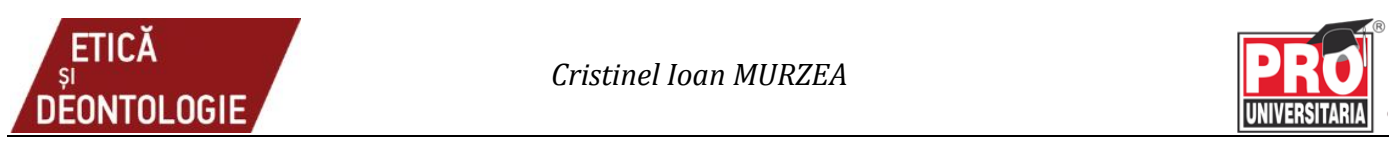

Un exemplu sugestiv în acest sens este oferit de definiția științei dreptului pe care o găsim în ultima perioadă din istoria dreptului roman, definiție consemnată în Institutele lui Justinian, în cartea I, Titlul I, care arată următoarele - „Jurisprudentia este divinorum atque humenorum rerumnotitia, justiat que iniustiscientia" - (știința dreptului sau jurisprudența este cunoașterea lucrurilor divine și urmare știința a ceea ce este drept și nedrept) (Molcut, Oancea, 1993, p. 6).

În sinteză se poate constata din definiția de mai sus că dreptul se exprimă ca știință prin valori de ordin moral precum dreptatea și umanismul, el oferind cadrul obiectiv necesar în vederea direcționării conduitei subiectelor de drept în circuitul juridic dat de sistemul normativ instituit în acest sens.

Simbioza între drept și morală în statul roman în statul roman este atât de evidentă încât termenul - „a equitas” - are o dubla semnificație, una morală cât și una juridică, arătându-se că se impune ca statul să fie condus prin cumpătare conform adagiului - „aequitate rem publicam qerere”.

Echitatea astfel, ca dimensiune morală, nu rămâne un concept în sine, ci ea se manifestă prin funcțiile și scopurile dreptului, fapt ce l-a făcut pe însuși ilustrul orator și jurist Cicero să confunde în plan conceptual - „aequitas cu juscivilae” - astfel aplicarea și garantarea principiului echității trebuia asigurat prin laborioasa „activitate de interpretare și aplicare a dreptului” (Molcut, Oancea, 1993, p. 26).

Jurisconsulții romani aveau să arate că justiția are drept principal comandament asigurarea bunăstării individuale cât și a societății în genere, având la bază respectarea moralei și a tradițiilor statului roman.

\section{Referințe}

Djuvara M., (1913), Le fondement du phenomene juridique (Quelques reflexions sur les principes logiques de la connaissance juridique), Paris, Librairie Sirey.

Djuvara M., (1936), Drept și sociologie, București, Editura ISP Bucuresti.

Durand G., (1986), Au rapportentre le droit et l'etique, vol. 20, nr. 2, Paris, Themis.

Gifford A.E., (1967), Droit romain et ancien droit francais, Tom. II , Paris, Dalloz.

Hanga Vl., (1978), Drept privat roman, București, Editura Didactică și Pedagogică.

Jacotă M.-V., (1977), Curs de drept roman - Jus pesonarum- Jus rerum, Iași.

Molcuț E., Oancea D., (1993), Drept roman, București, Casa de editură și presă „Șansa” - SRL.

Molcuț E., (2011), Drept privat roman, București, Editura Universul Juridic.

Oancea D., (2009). Introducere în dreptul roman, București, Editura C.H. Beck.

Popa V.V., (2004), Drept privat roman, București, Editura All Beck.

Perrot E., (1937), Precis elementaire de droit romain, Paris, Societe Anonyme du Recueil Sirey.

Roubier P., (1951), Theorie generale du droit, ed. 2, Paris, Societe Anonyme du Recueil Sirey.

Del Vecchio G., (1995), Lecții de filosofie juridică, București, Editura Europa Nova. 